\title{
FACULTY IN CONTEMPORARY KYRGYZSTAN: REACTIONS TO REFORMS
}

\author{
Martha Merrill ${ }^{1}$ \\ Kent State University, USA \\ Janara Baitugolova \\ Kyrgyz State University named after I. Arabaev, Kyrgyz Republic \\ Chynarkul Ryskulova \\ American University of Central Asia, Kyrgyz Republic
}

\begin{abstract}
After Kyrgyzstan's independence, reforms were implemented in higher education: new degrees, credit hours, private institutions, tuition in public institutions, and independent accreditation. However, faculty reactions to these reforms have not previously been studied. The authors conducted 57 interviews in four locations over three years. Our findings show that, first, interviewees discussed all kinds of changes in higher education and society. Second, participants were undergoing "concurrent stresses" (Anderson, Goodman, and Schlossberg, 2012) - their personal as well as professional lives were changing. Third, opinions differed. We analyzed these according to three of Schlossberg's " 4 S's": differences in faculty selves, situations, and support systems. However, few participants described strategies for dealing with the changes. Fourth, nearly all spoke of the reforms as something not under their control. Fifth, very few faculty members described the changes as unilaterally negative or positive. Most said, "I like this, but not that."
\end{abstract}

Keywords: Kyrgyzstan, faculty, reforms, higher education, tertiary education, Bologna Process external dimension, Schlossberg transition theory

${ }^{1}$ Correspondence: Kent State University, 411B White Hall, P.O. Box 5190, Kent, OH 44242-0001, USA; Email: mmerril@kent.edu 


\section{Introduction}

When the Soviet Union was dissolved on December 26, 1991, the fifteen successor nations faced many challenges. For the new nations in Central Asia, identity questions formed the background to almost every decision. Citizens asked: What should be the role of Islam in our country? Who or what should be represented on the national currency? Who are the heroes of our nation? Is the state multi-ethnic, or does the titular nationality have special privileges? Is there a state language? And what alphabet should it be written in? What should be included in the history books? (Adams, 2010). All of these decisions required reforms in not only university curricula, including history, languages, economics, anthropology, politics, and religion, but also in university structures, as educational policy borrowing (Ochs \& Phillips, 2004; Silova \& Steiner-Khamsi, 2008; Steiner-Khamsi, 2010) could signal a new orientation, for example, toward Europe and away from Russia.

The Soviet system of higher education - a first degree of five years (diplom), with an emphasis on contact hours, time in class with the professor, rather than independent work, followed by a Candidate of Sciences (kandidat nauk), often with research on a topic chosen by a scientific supervisor, and a Doctor of Sciences (doctor nauk), rarely awarded to anyone under 40 - was followed only by countries in the Soviet orbit. The system was centrally controlled, with curricula, including the number of hours devoted to each subject, designed and approved by committees of the Ministry of Education, and with degrees awarded by the Ministry or, for higher degrees (called "scientific degrees"), by the Higher Attestation Commission. Universities did not have the authority to design curricula or to award their own degrees (Popovych \& Levin-Stakevich, 1992).

After 1991, since the Soviet Union no longer existed, the new nations needed to consider what should happen to the Soviet system of education. The future it was preparing students for also no longer existed. The new future, however, was both uncertain and, at least in Kyrgyzstan, hotly debated. In the first decade and a half after independence, Kyrgyzstan, among the smallest, poorest, and most open of the successor states, readily accepted a variety of donor-funded projects, leading to a higher education system lacking in coherence (Merrill, 2012), where students at the Kyrgyz-Turkish Manas University literally were studying in a different language from those at the Kyrgyz-Russian Slavic University. Some programs, even within the same university, awarded diploms and some awarded bachelor's degrees; some programs used contact hours to measure progress and others used credit hours. Master's degree programs and traditional Soviet-era aspirantura programs existed side-by-side. Clearly, such a system - or non-system - was untenable in the long run.

On August 23, 2011, the Government of the Kyrgyz Republic issued a decree requiring all universities to implement Bachelor's and Master's degrees, using credit hours, by the next fall, (Merrill \& Ryskulova, 2012; Ministry of Education and Science of the Kyrgyz Republic, 2011). These reforms paralleled those agreed to in the Bologna Process (European Higher Education Area, n.d.), which by then counted almost all European countries as members (Belarus joined in 2015 and San Marino in 2020). Important allies, where Kyrgyzstani students often studied, were members: Turkey joined in 2001, Russia in 2003, and Kazakhstan in 2010. Kyrgyzstan can not become a member of the Bologna Process, because the membership criteria adopted by the Ministers responsible for higher education in the Bologna Process countries and published in the Berlin Communiqué (2003, p.8) require

that members sign the European Cultural Convention, and that in turn requires countries to be democracies and to have territory in Europe. A small part of Kazakhstan technically is in Europe (CIA, 2020a; Merrill, 2019), but Kyrgyzstan is entirely in Asia. Its higher education system can adopt Bologna Process reforms, but Kyrgyzstan can not join the Bologna Process. 
According to the 2011 decree, Bachelor's degrees in Kyrgyzstan were to be four years and Master's two, with exceptions for medical degrees, conservatory degrees, and a few others. The system was phased in: in 2012, all first-year entering students pursued Bachelor's degrees, while those who had entered a year earlier continued in five-year diplom programs. In 2013, first and second-year students were in the new system; in 2014, first, second, and third-year students were studying for Bachelor's degrees, and so on. Since the Bachelor's is four years and the diplom was five, in the spring of 2016, the first Bachelor's students and the last diplom students graduated simultaneously.

The requirement to use credit hours, in the 2011 decree (Government of Kyrgyzstan, 2011, August 23) applied only to student workloads. Faculty workloads are still calculated in contact hours. ${ }^{2}$ According to Postanovlenie \#18 of the Kyrgyz government (Government, Postanovlenie \#18, January 19, 2011), the factors that should be used to determine faculty salaries are the academic and position titles (professor, dotsent, senior instructor, instructor/ assistant, assistant-intern), and the scientific degrees (Doctor Nauk and Kandidat Nauk). The most recent updating of the Law on Education (Ministry of Justice of the Kyrgyz Republic, 2019) adds the Ph.D. to the list of scientific degrees that should be taken into account. Government decrees also list the number of hours professors in different categories are expected to work in an academic year (Ministry of Education and Science of the Kyrgyz Republic, 2011).

On May 15, 2014, the Minister of Education, Kanat Sadykov, announced that state attestation of higher education programs would end and be replaced by independent accreditation (Kudryavtseva, 2014). Defining the legal requirements for establishing independent accreditation agencies and the criteria by which they would evaluate programs took nearly two years, during which time university program evaluation was in a kind of limbo (Merrill, 2016), raising the question of whether or not students graduating from programs that should have had their five-year updates would have valid degrees, but finally independent accreditation started in 2016 (with a few pilots performed earlier). By 2019, five agencies were legally constituted (Ryskulova, 2019), with two of them, EdNet (n.d.) and the Agency for the Accreditation of Educational Programs and Organizations (AAOPO, no date) being most active. Criteria, loosely based on the European Standards and Guidelines (ESG, 2015), require higher education institutions to consider the opinions of substantially more stakeholders than those whose input was required in the state attestation system, and thus many professors have participated in compiling mountains of documents -150 of them, according to a colleague in the pedagogical faculty at the Kyrgyz National University, whose program was scheduled to go through accreditation in the fall of 2019 (personal communication, July 15, 2019).

Changing the country's degree system and how progress toward degrees is measured (with substantial implications for teaching loads) and changing how educational quality is assessed would, by themselves, be earthquakes in any higher education system. However, higher education in Kyrgyzstan also has been transformed in other significant ways in the years since independence.

New regional universities were established in Batken, Naryn, and Talas, and the number of public universities has grown from 10 at independence (Ministry of Education and Science of the Kyrgyz Republic, 2019; Ryskulova, personal communication, July 2019) to 32 in 2019 (Ministry of Education and Science of the Kyrgyz Republic, 2019). Private

\footnotetext{
${ }^{2}$ The American University in Central Asia uses credit hours to calculate faculty salaries, and a colleague reports that Ala-Too University does as well. We have not been able to confirm that this is the case at any of the other internationally-focused universities.
} 
universities were allowed; by 2019, 33 had been established (Ministry of Education and Science of the Kyrgyz Republic, 2019). ${ }^{3}$ Two universities were formed by government agreements with other nations: the Kyrgyz-Russian Slavic University named after Yeltsin was opened in 1993 (Kyrgyz-Russian Slavic University, 2019) and the agreement establishing the Kyrgyz-Turkish Manas University was signed in 1995 (History, n.d.).The University of Central Asia was founded by an intergovernmental treaty, agreed to by the presidents of Kyrgyzstan, Kazakhstan, Tajikistan, and the Aga Khan, in 2000 (University of Central Asia, n.d.). The Kyrgyz-American Fakultet of the National University became an independent university, now called the American University in Central Asia, in 1997 (American University in Central Asia, n.d.).

As the existence of all of these new higher education institutions suggests, new groups of students have begun to attend universities, with new purposes. Simple population growth, plus the population distribution across Kyrgyzstan's age pyramid, is one factor: by 2020 Kyrgyzstan's population was estimated at nearly 6 million, and $46 \%$ of the population was aged 24 and under (Kyrgyzstan, 2020). Moreover, unemployment for youth aged 15-24 is estimated to be over 14\%; for males, the figure is $10 \%$, but for females, it is $22 \%$ (CIA, 2020b). As DeYoung (2011) pointed out, by the time he wrote his book, higher education enrollments in Kyrgyzstan had quadrupled from their Soviet-era numbers. Thus, he concludes, for some constituencies, the latent functions of higher education - for the government, avoiding the disruptions dissatisfied unemployed youth might cause; for the students and families, the prestige of a diploma (see also Jonbekova, 2019) coupled with, for the young people, social life in the capital and possible connections for finding a job - outweigh the manifest function of actually getting an education.

The first law "On Education" passed after independence, in 1992, permitted both private education and tuition charges at public institutions. By the 1993-94 academic year; $7.6 \%$ of students enrolled in Kyrgyzstani public higher education institutions were contract, or tuition-paying, students, where before all students were supported by the state (Mertbaugh, 2004; Tiuliundieva, 2008). At the time Tiuliundieva published her article (2008; Russian original 2006), the proportion of contract students had reached $85 \%$. State-supported students now are referred to as "budget" students. Who is eligible for state support is determined by students' scores on the ORT, the Obshe Respublikanskoie Testirovanie or General Republic Test, which is, in effect, a national admissions test (Center, n.d.; USAID in the Kyrgyz Republic, 2017). The ORT itself is another innovation, launched by the then

3 The website of the Ministry of Education and Science of the Kyrgyz Republic (https://edu.gov.kg/ru/, last accessed April 26, 2020) gives three different numbers on three different web pages for the total number of higher education institutions in Kyrgyzstan. On the page simply titled "ВУЗы” (HEIs) (https://edu.gov.kg/ru/high-education/universities/) the Ministry states, "В республике функционирует 50 высших учебных заведений, из них государственных 31 , негосударственных - 19". [In the Republic function 50 higher education institutions, of these, state 31, nonstate 19.] On the page titled Высшее образование и послевузовское профессиональное образование [Higher education and postgraduate professional education] https://edu.gov.kg/ru/high-education/vysshee-obrazovanie-iposlevuzovskoe-professionalnoe-obrazovanie/), the Ministry states, "В Кыргызстане насчитывается более 50 высших учебных заведений”, [There are more than 50 higher education institutions in Kyrgyzstan] and then lists 64 [by the first author's count]. Finally, on the page titled Система ВУЗов [System of HEIs] (https://edu.gov.kg/ru/high-education/unis-system/), with the names, phones, and addresses of the institutions (several of which are not correct), 32 state and 33 non-state institutions are listed, for a total of 65 . We have chosen to use the last list, with the largest total number and most complete information. 
Minister of Education, Camilla Sharshekeeva, in 2002 (USAID in the Kyrgyz Republic, 2017; Drummond, 2020) in an effort to combat corruption in university admissions. As an additional way of generating income, institutions, particularly medical schools, began to recruit international students (Jenish, 2012). Given the proximity of South Asia, and the numbers of students from that region interested in medical education and unable to enter universities at home, the medical schools at both Osh State University and the International University in Kyrgyzstan began offering programs in English. In the 2018-2019 academic year, according to Bubugulsin Akilbekova, the Vice Rector for International Relations at the International University, South Asian student enrollment there topped 5000 (personal communication, July 5, 2019).

\section{Purposes}

Despite the enormity and diversity of the changes to higher education in Kyrgyzstan, faculty opinions of the reforms had not been studied. Our purpose thus was to understand faculty reactions to the reforms, as faculty work is essential to the success of higher education in any context. The first set of interviews took place in an urban area, with faculty in one discipline. In order to increase the breadth of responses, the second set took place at a regional university, with faculty in a variety of disciplines. Opinions of the faculty in the two groups differed, and we then added interviews in a second urban area and at a second regional university, all with the goal of understanding faculty reactions to the plethora of changes in the independence era.

\section{Theoretical Framework}

As noted, the aim of the research was to explore faculty responses to a great diversity of reforms. Because we were interested in individuals going through transitions, we chose Schlossberg's Transition Framework (Anderson, Goodman, \& Schlossberg, 2012), which focuses on individuals, to analyze their responses. The framework was designed to apply to one primary personal transition, such as marriage or the loss of a job, and all the ripple effects that caused, including changes in "roles, relationships, routines, and assumptions" (p 39). As faculty in Kyrgyzstan have had many transitions to react to, rather than analyzing each one, we focused on the "coping resources" (p. 39) professors have, what Schlossberg calls "the four S's" - the situation, the self, the support, and the strategies available. The situation may have many characteristics (p. 62); two that were important in our analysis were that for most interviewees, each situation was one of many concurrent stresses, and almost always, the transition was not one that the participant could control. The "self" of each person also varied - degrees earned, languages spoken, discipline taught, career stage. "Support" could be personal - family and friends - or professional, from the institution or external lectures and trainings. "Strategies" might include trying to control the situation, through individual or collective action, focusing on positive elements of the transition, or modifying one's attitude toward it. These four categories proved useful in analyzing the faculty members' differing reactions to reforms.

\section{Materials, Methods, and Evidence}

The research for this project was qualitative, exploratory and evolving. The researchers conducted 57 semi-structured interviews with faculty and analyzed documents related to university reforms. Despite the extent of the reforms in Kyrgyzstan, faculty attitudes about them had not been the focus of research previously. DeYoung's 2011 book contains a number of interviews with faculty at "Bishkek New University," but the emphasis 
of his book is on students and the choices they are making. In addition, his research took place before the shift to Bachelor's and Master's degrees and credit hours, and before the implementation of independent accreditation, so the faculty in his book do not discuss those issues. Other authors - e.g. Merrill, 2012; Shadymanova and Amsler, 2018 - have focused on higher education policy changes in Kyrgyzstan, but not faculty attitudes toward those changes. Kataeva and DeYoung (2020) looked at faculty attitudes, but in Tajikistan, drawing on interviews conducted with 26 professors at four universities in the capital city in the summer of 2013. Frost and Kambatyrova (2020) and their colleagues studied the opinions of school leaders in Shymkent, in Kazakhstan, who were charged with implementing reforms, but not professors. Our study in Kyrgyzstan thus was exploratory; it does not build on a preexisting body of literature.

The structure of our project developed, as the results from the first set of ten interviews, by one of the researchers, in 2015 and 2016, in an urban area, with faculty who taught in pedagogical programs, made us wonder if different participants would have different perceptions. Therefore, early in 2017, a second researcher interviewed twenty professors from a variety of disciplines at a regional university, and did indeed find different attitudes toward the reforms and different emphases about which issues were important. As a result, the following summer (2018), all three of us travelled to a second urban area and to a second regional university. We conducted 19 interviews in the urban area and eight at the regional university, and obtained a more nuanced portrait of the factors affecting faculty attitudes. We began to discuss some of the factors affecting faculty attitudes in terms of Schlossberg's four S's - self, situation, support, and strategies (Anderson, Goodman, \& Schlossberg, 2012). As discussed below in our findings, the characteristics of the individual faculty, the situations they were working in, and their personal and professional support systems all seemed to influence their attitudes toward the academic and institutional reforms they were experiencing.

Nevertheless, the research remains exploratory, as it involves a limited number of faculty, only from public universities, and the reforms continued as our research continued, so that, for example, by 2018 accreditation had become a major issue of discussion.

When we refer to the interviewees in the text, we use $\mathrm{U} 1$ and $\mathrm{U} 2$ for Urban Location 1 (2015 and 2016) and Urban Location 2 (2018), and R1 and R2 for Regional University 1 (2017) and Regional University 2 (2018). We interviewed 40 women and 17 men. As noted, we did ten interviews in $\mathrm{U} 1,19$ in $\mathrm{U} 2,20$ in $\mathrm{R} 1$, and eight in R2. All names are pseudonyms.

In addition to the laws creating the BA/MA system and accreditation, various documents mandating reforms and policies were referred to by participants, so we located and analyzed those documents. We also wanted to know at what level (Ministry, individual university, accreditation agency, etc.) documents originated, in order to know how much authority they carried. Two of the researchers, both of whom are native speakers of Kyrgyz and fluent in Russian, located, read, summarized, and translated the documents.

\section{Findings}

Our findings fell into five major categories. First, interviewees discussed all kinds of changes in higher education, not just formal changes such as degree structures. Second, participants were undergoing what Schlossberg (Anderson, Goodman, \& Schlossberg, 2012) calls "concurrent stresses" - in independent Kyrgyzstan, it is not only their professional lives that are changing. Third, faculty had differing opinions about the reforms. Here, we found Schlossberg's " 4 S's" to be a useful framework for analysis: differences in faculty selves, situations, and support systems influenced differences in opinions. However, few participants 
could describe strategies for dealing with the changes. Fourth, nearly all of the participants spoke of the reforms as being done to them, as something not under their control. Fifth, very few faculty described all of the changes as negative, or all of them as positive. Most said, "I like this, but not that."

\section{Changes in Higher Education at All Kinds of Levels}

First, the participants discussed all kinds of changes - those connected to the Bologna Process, those initiated by a rector, those due to economic changes and the initiation of "contract" (fee-paying) students, those required by the accreditation process (or by someone's perception of the accreditation process), those made possible by an international donor, and more, including those beyond the control of institutions or the Ministry of Education, such as how young people now have different goals than the respondents did in Soviet times and how internet connections and other forms of technology are omnipresent. All were changes to higher education from how our participants had experienced it before independence or in their own student days, and all affected them.

For example, Barchyn (U2, interviewed June 5, 2018), discussing changes in young people, said that even her own children "leaned toward making money" and were "not patient."Ashyr (R1, January 24, 2017)made a similar observation: "Unfortunately, youth value material wealth [more] than moral wealth and education."Eldana (U2, June 7, 2018) recalled, "When we were students, we had no internet, no technology, no copies, no books." She added that when she was a student, "It was a celebration to use a tape recorder; it was a holiday.” Alma (R1, January 26, 2017), discussing changes in university life, attributed them to "changes in Kyrgyz society overall - social, political, economic." She added, "We should change according to changings of society."Aijan (R2, June 21, 2018) similarly attributed university changes to changes in society, adding, "the appearance of an alternative higher education system" made teachers think about what they were doing. Ruslan (R2, June 20, 2018) saw similar causes for reforms, and he considered contexts: "The Soviet System was good for that time, and the Bologna Process is good for the present time."

Most participants had positive reactions toward mobility and international connections, regardless of the source of those connections. Janara and Nurgul (U2, both interviewed on June 5, 2018) said that mobility programs were a plus of the Bologna Process, but then both discussed, as an example, a ten-day program in Malaysia they had participated in that had been arranged through their university. Mahabat (U2, June 7, 2018) also was positive about mobility, mentioning both an Erasmus program in Spain and a Mevlana program in Turkey. Erlan (R1, January 19, 2017), discussing his international consulting and seminars, mentioned work with the Eurasia Foundation, the Russian READ program, and UNESCO alongside three ERASMUS and TEMPUS grants. Other participants from R1 mentioned "European experience," a program at the University of Pisa in Italy, one in India funded by Indian Technical and Economic Cooperation, a journalism program in St. Petersburg, and scientific research at Tomsk State University in Russia.

The professors from U1, by contrast, were generally more senior figures for whom longer-term experiences abroad were not easy options. Although four of them had attended conferences abroad, their focus was more on curricular changes and other elements of reforms at home. This may be a reason for their generally more negative perceptions of the reforms; what more mobile participants considered to be a major advantage of the reforms was not part of their experience. 
Changes at universities thus include but go beyond changes designed to parallel Bologna Process reforms. Changes in society overall, changes in young people and their goals, and mobility programs, regardless of the sponsor, all were discussed by interviewees.

\section{“Concurrent Stresses” in Other Parts of Participants' Lives}

Second, the adjustments participants were experiencing were not simply in their professional lives. Colleagues and family members had moved abroad, either temporarily or permanently. Friends and family members had become religious, and some participants felt pressure to make choices about their beliefs. (We did interviews in U2 during Ramadan, so having lunch, or tea during interviews, raised this question.) The internet and mobile phones brought new content into family discussions, and traditional respect for elders sometimes was undermined. Questions were raised about women's roles. Formerly porous borders now had checkpoints, and visiting relatives even a few kilometers away had become difficult for some participants.

Schlossberg (Anderson, Goodman, \& Schlossberg, 2012) raises the notion of "concurrent stresses." A job change combined with a salary loss and a move to a new neighborhood and new schools for children is a more difficult and complex transition than a job change without a move and family and financial changes. As residents of Kyrgyzstan experienced political and economic transformations, many of our interviewees were going through variations in multiple aspects of their lives simultaneously, thus exacerbating the stresses of professional transitions. "Change fatigue" can contribute to a wish for a return to a simpler, more stable time.

For example, Asel (U1, August 8, 2016) gave one of the most emotional interviews. She had been teaching in the same department for 38 years, but under new employment criteria, specific to her university, it appeared that she would lose her job. Then, because she had a full teaching load, she was rehired. With only a five-year diplom, in a city with others qualified to teach in her field, close to retirement age and unable to go abroad for retraining, Asel had few options. For her, the changes from her stable life in Soviet times were entirely negative.

Moreover, new policies in higher education institutions were not always coordinated with parallel developments elsewhere in the society. For example, as noted, starting in 2012, all institutions (with a few exceptions like the Art Institute and the Medical Academy) had to switch from five-year diploms to four-year Bachelor's degrees and from contact hours to credit hours, one year at a time. However, previously anything less than the five year diplom was considered "incomplete higher education" and for several years, school principals in some regions continued to consider Bachelor's graduates as unqualified to be teachers (Baitugolova, personal communication; Maksat, R1, January 25, 2017; see Jonbekova, 2019, for parallel perceptions in Kazakhstan and Tajikistan, and Shadymanova \& Amsler, 2018, for disciplinary differences in perceptions of the bachelor's being a sufficient qualification). One of the professors we interviewed agreed: "To my mind, a BA is not enough to train a full specialist." (Erlan, R1, January 19, 2017).

In addition, as of the summer of 2020 , faculty still are paid according to a formula based on the degrees they have and the contact hours they teach, seven years after credit hours were mandated for measuring student progress, but not faculty teaching loads. Thus faculty schedules include assignments with oxymoronic titles such as "independent work with faculty," so that teachers have enough contact hours on their schedules to maintain their former salaries. 
However, salary payments and employment procedures were not uniform across the interview sites. Jyide (R1, January 13, 2017)said, "University teacher's salary is low and unsatisfactory. For example, high school teachers [are] paid more than us." At one of the universities in $\mathrm{U}_{2}$, on the other hand, the rector was trying to position the university as one of the strongest in the country, and, at one point, faculty salaries were increased six times in five years (Internal university document, 2013). In addition, Shirin, Janara, and Nurgul (U2, all interviewed on June 5, 2018) each mentioned that faculty were given bonuses for completing advanced degrees. Indira and Ruslan (R2, both interviewed on June 20, 2018) reported that a similar bonus system had been implemented at that regional university.

Technological changes were viewed positively by some faculty and less so by others. Elmira (R 1, January 17, 2017) said, "I can use electronic variants of materials and work with Drop Box."Nurjan (U1, August 12, 2016), on the other hand, complained about the "electronic grade sheets" recently introduced at her university. Not only did older faculty who had limited experience with computers find these forms cumbersome and difficult to fill out, but also, faculty were still required to complete paper grade forms, so the technology doubled their work. Moreover, some faculty thought the electronic grading forms were a way for the registrar's office and other academic administrators to monitor their performance.

\section{Responses to the Reforms Are Not Uniform}

Third, faculty perceptions of the reforms are not uniform, but rather varysubstantially. Schlossberg's transition theory (Anderson, Goodman, \& Schlossberg, 2012) helped us to analyze the reasons for the differences, particularly her categories of four S's that affect perceptions of transitions: the self, the situation, the supports available, and the strategies the individual has for dealing with the situation.

Variation in attitudes toward reforms can be seen as due to differences in the selves (e.g. whether the person has only a diplom vs. doctor nauk; the person's discipline - hard scientists often thought the reforms weakened what they perceived as strong Soviet-era science; those who have good English had more opportunities for mobility and alternative or supplementary job prospects, such as tutoring or working with NGOs). Chynar (R1, January 13, 2017), for example, felt confident and competent: "I have experience and skills. I have participated at different seminars and trainings."

Perceptions also varied based on the situation participants were in (e.g. lack of options for rural interviewees for mobility and job change and training, vs. urban, but at the same time, urban faculty are more easily replaced and thus have greater job insecurity; the R1 university had an active head of the International Department and thus many opportunities for student and staff mobility; at two other universities, the rector had instituted substantial salary bonuses for faculty who completed additional degrees). Chynar (R1, January 13, 2017) complained about the workload situation: “Teachers don't have time and aren't paid for scientific work and only a little for administrative work. It has negative impacts for the quality of the student's education." A colleague added: "University teacher's work is difficult and complicated. ...Y You have to work hard and get scientific degrees."(Alma R1, January 26, 2017). Moreover, at this rural location, "Sometimes we lack [good] conditions. For example, in winter we might not have electricity." (Maksat R 1, January 25, 2017).

Personal and professional supports for those going through transitions also varied; for example, one participant mentioned a mother-in-law who complained about the participant working on Sundays as her program prepared for accreditation, while another said that her husband was an academic at another institution in the same city; his program had been through accreditation a few months earlier, and he understood what she was experiencing. 
Salkyn (R1, January 30, 2017) complained, "Sometimes I work all day and I cannot take care my family." On the other hand, a younger colleague, who lived at home, said, "I create new ideas and my parents and colleagues always support me.” (Jamilya, R 1, January 17, 2017).

Few participants had strategies for coping with the changes; many simply accepted them. For example, although the majority of the 2016 participants, who were interviewed as the new independent accreditation process was coming into effect, had negative opinions of that process, and many complaints, none of those respondents proposed going to the Ministry or to his or her rector or to anyone else to request changes in the process or in the accreditation criteria. Coping mechanisms generally were limited to finding ways to manage time or to learn about newly-required technology: "I like to start the work quickly and to finish quickly" (Indira, R2, June 20, 2018). Raushan (U2, June 7, 2018) added, "I make up a schedule for myself and at home I do only house work; at work I do the work related to my job, and from 10 to 13 [1 pm on a 12-hour clock $]$ is the time for class preparation." Aijan (R2, June 21,2018 ) tried to learn more in order to cope with the new requirements, but did not challenge the requirements themselves: "I try to organize my time properly to balance between teaching and research. Attended computer courses. I usually write down every step what follows what in detail. I attended courses in Bishkek. This helps me.”

\section{Lack of Control over Reforms That Affect Them}

Fourth, related to the lack of strategies for dealing with the changes was a strong sense of a lack of control over what was happening: most of our participants perceived of the changes in higher education as something done to them, not by them or with them. Frost and Kambatyrova (2020, p.445), in their study of school leaders in Kazakhstan, observed a similar sense of lack of control:

The senior leaders we spoke to felt the pressure of expectations from the centre that reforms are to be carried out within a short time frame even though the provision of the tools and resources necessary for implementation may be inadequate.

In Kyrgyzstan, five-year degrees were replaced with four-year Bachelor's degrees and content had to be cut and adjusted; the university Monitoring Department demanded new teacher evaluation documents; the accreditation process required meetings with external stakeholders and criteria faculty hadn't thought about before; and contract students who were paying for their education felt a sense of entitlement. Moreover, technological change also created new situations that were not under faculty control: access to the internet meant that other teachers are checking YouTube and coming up with more interesting lessons, and simultaneously, students are finding online sites to plagiarize from.

Schlossberg (Anderson, Goodman, and Schlossberg, 2012) discusses control as being an important factor in attitudes toward transitions; the initiator of a divorce will have a different attitude toward that transition than will a spouse who is blindsided by the announcement; the student rejected by a chosen university will have a different reaction than one who herself makes the decision not to attend. The lack of input into decisions affecting them was a source of frustration for some participants, but was considered "business as usual" by others who were used to Ministries of Education and other authorities making pronouncements that the participants had to adjust to.

Bermet (R2, June 21, 2018), the mother of four small children (and "husband is like a fifth child"), spoke wistfully of her own student days. Now, of her group mates, "Jyldyz is in 
America, Gulzat also ... Grisha is in Moscow, and also Valya." She, with only a diplom from the same institution where she now works, and her family responsibilities, can not envision a future that takes her away from her provincial city. In her case, lack of control is based in the self, the situation, and lack of support from her husband and others for change.

The interviewees in U1 have different "selves" than Bermet; they were older, with more experience, and several had kandidat nauk degrees. Yet they, too, felt a lack of control over the mandated shift to Bachelor's and Master's degrees and the implementation of credit hours. A professor and administrator with 23 years of teaching experience (Ermek, July 24, 2015) expressed the skeptical attitude of many of his colleagues towards the new Ministrymandated standards, noting that they did not take into account the poor socio-economic conditions in the country and the lack of preparedness of higher education institutions to introduce new student-centered curricula with a competency-based approach. He did not believe that the new standards would be successful: "We changed the form but the content of the curricula remains the same." This idea was supported by another professor from a different institution, who said, "The titles of the courses became very loud, but the content is the same." Yet she also said:

$90 \%$ of the institute's curriculum changed when the shift from the five-year specialist degree to the BA was instituted in 2012. The institution reduced not only the contact hours but also the number of courses in its curriculum, leaving 30 courses out of the 50 in the previous curriculum. For instance, two major courses, Political Science and Conflict Resolution, were combined, and a threesemester long course now is taught in one semester. (Aida, August 8, 2016)

Both Ermek and Aida, despite their critiques of the new standards, saw them as "a done deal," something problematic and worth complaining about, but not something that they had strategies for resisting or overturning.

\section{"I Like This, but I Don't Like That"}

Fifth, few of our participants had an "all or nothing" attitude toward the reforms they were experiencing. For example, they might be opposed to the shortening of the first degree and the resulting curricular changes, but like the opportunity for mobility abroad for themselves and their students. A number felt uncomfortable assigning and grading independent work by students, as they had never done such work themselves, but also liked the precision of a 100-point grading scale (which many thought was required under Bologna) and not having to sit through days of listening to students' oral examinations. Many found accreditation to be an enormous amount of work, but also mentioned how interesting it was to understand elements of the university beyond their own department, to get to know new colleagues, and to hear stakeholders' feedback on student achievements.

Examples of "this change is positive, but that one is negative" are plentiful. At R1, the regional university with a strong international office where many participants spoke positively about exchange programs for themselves and their students, the Monitoring Office had implemented new requirements, and faculty complained about the added paperwork. Ashyr (R1, January 24, 2017) said, “[Before] paper documents took one fourth of teacher's valuable time and now they take half the time." He added, "There are many paper documents and [this] influences negatively the education process." In addition, as faculty evaluation criteria were changing, one participant noted that it would be good if international mobility counted in the new evaluation process: "We value and appreciate academic degrees. It would 
be wonderful if we value international experiences and internships, too." (Jyide, R1, January 13, 2017). Another participant, returning from an exchange, found the infrastructure at R 1 to be lacking: "We don't have better conditions. I realized [this] when I studied in Europe." (Attokur, R1, January 23, 2017).

Despite these critiques, the majority of the participants whom we asked, "If you had to do it all over again, would you still become a professor?" answered in the affirmative. This question was not asked of the ten participants in the very first group, U1, but was asked of the 47 in R1, U2, and R2. Twenty-seven said yes and only nine responded with an unequivocal no. Many seemed not to have even considered any other option: Aigul (R1, January 16, 2017) was typical: "I can't imagine myself doing any other profession." Similarly, Indira (R2, June 20, 2018) said, "It was my childhood dream; I can not imagine myself without teaching." Guljan (U2, June 4, 2018) and Umar (U2, June 6, 2018) both mentioned family traditions; parents and other relatives had been teachers. Others were more reflective. Attokur (R1, January 23, 2017) said, "Teachers play an important role and determine the future of the country." Erlan (R1, January 19, 2017) quoted a Kyrgyz proverb: "Mugalim momoluu darak" - "A teacher is a tree with fruits." Those who said no sometimes seemed to have unfulfilled dreams: Elmira (R1, January 17, 2017) said, "I wanted to be a doctor," and Jamal (R1, January 18, 2017) replied, "I want to be a fashion designer."Gulnora (U2, June 7, 2018) responded, "So much work - I would rather be a lawyer." Aidana (R1, January 30, 2017), like several others, had a mixed response: "My answer is twofold: yes, from the professional side. It's good; you change for the better and improve yourself. No, from the financial view. The teacher's job has the lowest salary in the Kyrgyz Republic."

\section{Discussion}

Sebastien Peyrouse (2019, p. 6-7), in a critique of the EU's old and new Strategies for Central Asia, pointed out a number of flaws in the EU's education policies:

... the EU's belief that the Western education system could be transferred greatly underestimated the diversity of the post-Soviet space. By using a onesize-fits-all approach to post-Soviet countries, European education assistance has generally excluded local stakeholders (teachers, parents, and students) and ignored Central Asia's multiple historical, political, economic, social and cultural contexts and values. Meanwhile, Central Asian authoritarian regimes have significantly restricted foreign donors' access to local stakeholders. As a result, there has been little sense of local ownership of European education programmes.

His critique parallels those of others who have pointed out the need for local engagement and understanding local conditions in educational policy transfer (Ochs \& Phillips, 2004; Silova \& Steiner-Khamsi, 2008; Steiner-Khamsi, 2010; Eriksson, 2019; for the EU specifically, see Merrill \& Dukenbaev, 2011). In particular, Peyrouse notes the lack of EU engagement with local stakeholders. Although Central Asian faculty have been involved in specific TEMPUS and, more recently, ERASMUS+ projects, they have not been included in policy making. Such lack of inclusivity is not new; as long ago as 1981, Brian Holmes described the concept of "donor logic," the idea that certain donors have preferred strategies and tend to apply those strategies in diverse contexts (Holmes, 1981). Madeleine Reeves (2006, p. 194) provides an example of the results of not including local stakeholders. The 
director of a school in Batken, the poorest oblast in Kyrgyzstan, while very grateful for UNICEF teacher training workshops, comments:

I like the methodology they showed us, but we use it for only one lesson a week - we can't use it any more than that. Because you need all kinds of materials to be able to incorporate what they taught us - you need felt-tip pens and marker pens and large sheets of paper, and where do we get those from?

Such lack of consideration of "on the ground" effects is true not only for EU donors and policy makers; Kyrgyzstani policy makers as well rarely have consulted stakeholders in education, including faculty members. The lack of hearing faculty voices before policies were decided, and the lack of training and support for faculty trying to adapt to the dictates of those in the capital, for a number of reasons, means that reforms are not carried out as the planners envisioned.

First, the lack of hearing faculty voices leads to problems that are obvious to practitioners from the beginning, and which disrupt the reforms. For example, when the idea of credit hours was presented to faculty at the American University of Central Asia, the first higher education institution in the country to implement them, faculty immediately asked, "What does this mean for our salaries?". In the contact hour system, faculty were paid for the number of hours they were in contact with students. In a credit hours system, which emphasizes student independent work, faculty are in class substantially less time than before, and instead spend more time advising, mentoring, providing feedback, and designing innovative assignments. However, if the salary criteria system is not changed at the same time as credit hours are introduced, then faculty lose money, as they are compensated only for time in class and not for any of the new activities they are supposed to learn and practice. In an effort to maintain existing salary levels, as noted, higher education institutions have implemented classes with the oxymoronic title, "independent work with professor." Moreover, since faculty are not paid for developing or grading independent assignments, anecdotal reports suggest that few do this work.

Similarly, the creation of independent accreditation agencies by a decree from the center and the lack of local involvement or explanations and support structures means that many faculty perceive accreditation as being simply Soviet-style attestation done by different people. Numerous faculty described accreditation as preparing documents for inspection by external examiners; almost none described it as an opportunity for self-reflection, self-study, and planning for the future. Moreover, almost uniformly, faculty stated some form of "Thank goodness we have to do that only once every five years." The idea of continuous selfimprovement, supported by an Institutional Research Office that is regularly collecting data that will assist administrators and faculty in developing the quality of education, was not presented to the faculty we interviewed, nor supported by materials or workshops as part of the switch from state attestationto independent accreditation. Thus, many faculty see accreditation as attestation with different actors, a change in discourse only, and not one of substance.

Second, the lack of extensive programs to introduce and support faculty in the implementation of reforms means that the reforms are carried out differently in different contexts. Rather than there being a coherent system of restructuring, individual situations differ substantially. Considering Schlossberg's four S's - the self, the situation, the supports, and the strategies - makes clear how unsystematically the reforms have been implemented. 
Individual selves have had an impact. The first group of interviewees, in U1, were older, more experienced and more established than the younger professors interviewed later. The characteristics of those selves made them less able to take advantage of what participants in $\mathrm{R} 1$ and $\mathrm{U}_{2}$ found most attractive about the reforms: the opportunity to be involved in mobility programs and spend time abroad. Additionally, the initiative and activity of the Director of the International Department at R 1 made many more opportunities for mobility available for the faculty at that institution than were available to the faculty at R2. On the other hand, the rather narrow vision of quality held by the head of the Monitoring Department at $\mathrm{R} 1$ created what some interviewees there considered a great deal of busy work and detracted from a broader understanding of purposes of the changes, one that went beyond the benefit to the individual. Similarly, the entrepreneurial skills of one rector in U2, later emulated by the administration at $\mathrm{R} 2$, allowed faculty who completed higher degrees to receive financial rewards for doing so, whereas this was not the case at other higher education institutions.

At the same time, situations mattered. Faculty in the hard sciences almost uniformly criticized the Bologna Process. They came from disciplines that were well supported in Soviet times, with funding for their laboratories and prestige for their professions. Few of them learned English; Russian and perhaps German were the languages they needed. In the postSoviet era, with English as the language of the internet, and business, law and other professions gaining status, those in the hard sciences have become marginalized. Similarly, those who had pursued no more than a diplom now are disenfranchised. One of the most emotional interviews any of the researchers had was with an instructor in $\mathrm{U} 1$ who held only a diplom. For 38 years this had been enough for her to have a stable teaching position. Now, in the competitive and capitalistic market, the city is full of people with more education in her field, time abroad, and the qualifications to teach Master's level students. A few years from being eligible for her pension, she finds it difficult to maintain employment. Relatedly, an instructor with a trifecta negative situation - holding only a diplom; working at R2, a regional university without strong supports for faculty learning and change; and a personal situation as the mother of four small children - felt completely trapped and sad.

Support for faculty and their work varied widely. This would of course be true of personal situations; one young instructor in $\mathrm{U}_{2}$ had a husband who was also a professor, who completely understood the demands of the accreditation process, while another instructor, at the same institution, had a mother-in-law who complained when the professor came to the university on Sunday to prepare accreditation documents. However, professional support also varied widely. Faculty in U1 had easy access to seminars in the capital, workshops by accreditation agencies, and presentations by visitors from Europe. Those at R2, eight hours from the capital, searched on YouTube for explanations of the Bologna Process and asked young Bachelor's-educated Peace Corps volunteers for assistance.

Although the state had no coherent implementation policy for the switch from diploms and kandidat nauks to Bachelor's and Master's degrees, and for the transfer from contact hours to credit hours, individuals, many used to accepting decrees from above, also rarely had strategies for dealing with the reforms. Indeed, a number of respondents did not even understand our question about the strategies they used to cope with the new policies. The reforms were simply to be accepted.

\section{Significance and Conclusion}

In the early years of independence, Kyrgyzstan's higher education authorities received grants and loans, and their accompanying structures and policies, from a range of donors 
hailing from a range of countries and organizations. The result was a system that was chaotic, diverse, and lacking in integration (Merrill, 2012). Recent top-down reforms have focused on adopting elements of the Bologna Process: Bachelor's degrees, Master's degrees, credit hours, and independent accreditation. However, those reforms have been embraced (or in some cases simply tolerated) largely as discourse, and not as substance. The people most essential for carrying out the reforms - university faculty - have been both left out of the initial discussions and unsupported as they have attempted implementation. This is significant because enactment of reforms thus differs widely from institution to institution and region to region. Higher education in Kyrgyzstan therefore remains diverse in practice and unified and integrated only in discourse. This lack of coherence works against the nation's professed goals of coordinating its higher education system with the European Higher Education Area.

\section{Declaration of Interest Statement}

None of the authors have any conflicts of interest regarding this research. None of the authors received any financial support to conduct this research.

\section{References}

AAOPO (n.d) Агентство по аккредитации образовательных программ и организаций [Agency for the accreditation of educational programs and organizations]. http:/ / www.aaopo.kg/index.php?lang=ru

Adams, L. L. (2010). The spectacular state: Culture and national identity in Uzbekistan. Duke University Press.

American University of Central Asia. (n.d.). History of AUCA. https://auca.kg/en/auca history/

Anderson, M.L., Goodman, J., and Schlossberg, N. K. (2012). Counselling adults in transition: Linking Schlossberg's theory with practice in a diverse world (4th edition). Springer.

Berlin Communiqué (2003, September 19) Communiqué of the Conference of Ministers Responsible for Higher Education. "Realising the European higher education area". http://ehea.info/Upload/document/ministerial_declarations/2003_Berlin_Commu nique English 577284.pdf

Center for Educational Assessment and Teaching Methods (n.d.) Центр оценки в образовании и методов обучения. http://www.testing.kg/ru/

CIA. (2020a). Kazakstan - The world factbook. https://www.cia.gov/the-worldfactbook/countries/kazakhstan/

CIA. (2020b). Kyrgyzstan - The world factbook. https://www.cia.gov/the-worldfactbook/countries/kyrgyzstan/

DeYoung, A. (2011) Lost in transition: Redefining students and universities in the contemporary Kyrgyz Republic. Information Age Publishing.

DeYoung, A., Reeves, M., \& Valyayeva, G., eds. (2006). Surviving the transition? Case studies of schools and schooling in the Kyrgyz Republic since independence. Information Age Publishing.

Drummond, T. (2020) Higher education admissions regimes in Kazakhstan and Kyrgyzstan: Difference makes a difference. In I. Silova and S. Niyozov, eds. Globalization on the margins: Education and postsocialist transformations in Central Asia ( $2^{\text {nd }}$ edition) (pp. 95-124). Information Age Publishing.

EdNet. (n.d.). https://www.accreditation.asia/en 
ESG. (2015). Standards and guidelines for quality assurance in the European higher education area. https://enqa.eu/wp-content/uploads/2015/11/ESG 2015.pdf

Eriksson, S. (2019). Domestication of Travelling Reforms in Higher Education of Kyrgyzstan. Helsinki: Helsingin yliopisto. (Dissertation, University of Helsinki) http://hdl.handle.net/10138/307783

European Higher Education Area. (n.d.). European Higher Education Area and European Higher Education Area. http://www.ehea.info/

Frost, D., \& Kambatyrova, A. (2020). Researching internationalization and educational reform in Kazakhstan. In I. Silova and S. Niyozov, eds. Globalization on the margins: Education and post-socialist transformations in Central Asia pp. 431-454. Information Age Publishing.

Holmes, B. (1981). Comparative education: Some considerations of method. George Allen and Unwin.

Jenish, N. (2012). Export of higher education services in Kyrgyzstan. Institute of Public Policy and Administration Working Paper No.7. University of Central Asia. https://www.ucentralasia.org/Content/downloads/ippa_wps_en.pdf

Jonbekova, D. (2020). The diploma disease in Central Asia: Students' views about purpose of university education in Kazakhstan and Tajikistan. Studies in Higher Education, 45(6), 1183-1 196. http://doi.org/10.1080/03075079.2019.1628199

Kataeva, Z., \& DeYoung, A. (2020) The changing status of faculty work and life in the universities of Tajikistan. In I. Silova and S. Niyozov, eds. Globalization on the margins: Education and post-socialist transformations in Central Asia ( $2^{\text {nd }}$ edition) (pp. 147-165). Information Age Publishing

Kudryavtseva, T. (2014, May 15). Kanat Sadykov: We transfer from formal attestation to universities accreditation procedure by September 1, 2014. 24. kg. https://24.kg/archive/en/community/170486-news24.html/

Kyrgyz-Russian Slavic University. (2019). Yeltsin and KRSU. https:/ $/$ www.krsu.edu.kg/index.php? option $=$ com content\&view $=$ article\&id $=1273$ $\underline{\text { \&Itemid }=593 \& \text { lang }=\mathrm{en}}$

Kyrgyz Turkish Manas University (n.d.) History. http://intl.manas.edu.kg/en/about_manas/history

Merrill, M. C. (2012) Kasha and Quality in Kyrgyzstan: Donors, Diversity, and Dis-Integration in Higher Education European Education, vol. 43, no. 4 (Winter 2011-12), pp. 5-25.

Merrill, M. C. (2016). Kyrgyzstan: Quality Assurance—Do State Standards Matter?. International Higher Education, (85), 27-28. https://doi.org/10.6017/ihe.2016.85.9247

Merrill, M. C. (2019) International Accreditation in Kyrgyzstan and Kazakhstan: Different Rationales and Different Results. Asian Education and Development Studies, 9(4), pp. 465-478. https://doi.org/10.1108/AEDS-08-2018-0131

Merrill, M. C. and Dukenbaev, A. (2011) "Youth and Education" in A. Warkotsch, ed. The European Union in Central Asia London: Routledge Taylor and Francis (pp. 115-131)

Merrill, M. C. and Ryskulova, Ch. Sh. (2012) "Kyrgyzstan plans BA-MA system, with credit hours" International Higher Education, no. 68, Summer, pp. 18-20

Mertbaugh, M. (2004) Education in Central Asia, with particular reference to the Kyrgyz Republic. In S. Heyneman and A. J. DeYoung, eds. The challenges of education iCentral Asia (pp. 153-180). Information Age Publishing.

Ministry of Education and Science of the Kyrgyz Republic (2011),_Postanovlenie \#18 of the Kyrgyz government January 19, 2011. О введении новых условий оплаты труда работников образовательных организаций [On the introduction of 
new conditions for remuneration of employees of educational organizations]. https://edu.gov.kg/ru/docs/postanovlenie-pravitelstva-kr-o-vvedenii-novyhuslovij-oplaty-truda-rabotnikov-obrazovatelnyh-organizacij/

Ministry of Education and Science of the Kyrgyz Republic. (2011). The size of the official salaries of the teaching staff of educational organizations. https://edu.gov.kg/ru/docs/razmery-dolzhnostnyh-okladov-professorskoprepodavatelskogo-sostava-obrazovatelnyh-organizacij

Ministry of Education and Science of the Kyrgyz Republic. (2019). Система ВУЗов [System of higher education institutions]. https://edu.gov.kg/ru/higheducation/unis-system/

Ministry of Education and Science of the Kyrgyz Republic. (2019). История образования [History of education]. https://edu.gov.kg/ru/high-education/istoriyaobrazovaniya/

Ministry of Justice of the Kyrgyz Republic. (2011). Постановление Правительства Кыргызской Республики от 23 августа 2011 года . \#496 Об установлении двухуровневой структуры высшего профессионального образования в Кыргызской Республике [On the establishment of a two-tier structure of higher professional education in the Kyrgyz Republic]. http://cbd.minjust.gov.kg/act/view/ru-ru/92802

Ministry of Justice of the Kyrgyz Republic. (2019). ЗАКОН КЫРГЫЗСКОЙ РЕСПУБЛИКИ от 1 июля 2019 года № 780 внесении изменений в Закон Кыргызской Республики "Об образовании" http://cbd.minjust.gov.kg/act/view/ru$\underline{\mathrm{ru} / 111925 \text { ? cl=ru-ru }}$

Ochs, K., \& Phillips, D. (2004). Processes of educational borrowing in historical context. In D. Phillips and K. Ochs, eds. Educational policy borrowing: Historical perspectives (pp. 723). Symposium Books Ltd.

Peyrouse, S. (2019, June) Reconsidering EU education assistance to Central Asia (Policy Brief No. 37). EUCAM. https:// eucentralasia.eu/reconsidering-eu-education-assistanceto-central-asia

Popovych, E., \& Levin-Stakevich, B. (1992). The Soviet system of education. (A Pier World Education Series special report) AACRAO.

Reeves, M. (2006). Schooling in Ak-Tatyr. In A. J. De Young, M. Reeves, and G. K. Valyayeva, eds. Surviving the transition? Case studies of cchools and cchooling in the Kyrgyz Republic since independence (pp. 159-198). Information Age Publishing.

Ryskulova, Ch. (2019) Faculty Perspectives on Independent Accreditation of Pedagogical Programs in Kyrgyzstan. [Doctoral dissertation, Kent State University] https://etd.ohiolink.edu/!etd.send file?accession=kent1554899148722784\&disposition=inli $\underline{\text { ne }}$

Shadymanova, J., \& Amsler, S. (2018). Institutional strategies of higher education reform in post-Soviet Kyrgyzstan: Differentiating to survive between state and market. In J. Huisman, A. Smolentseva, \& I. Froumin, eds. 25 years of transformations of higher education systems in post-Soviet countries: Reform and continuity. Springer.

Silova, I., \& Steiner-Khamsi, G. (2008). Introduction: Unwrapping the post-socialist educational reform package. In I. Silova and G. Steiner-Khamsi, eds. How NGOs react: Globalization and education reform in the Caucasus, Central Asia, and Mongolia. Kumarian Press. 
Steiner-Khamsi, G. (2010). Presidential address: The politics and economics of comparison. Comparative Education Review, 54 (3), 323-342.

Tiuliundieva, N. (2008). The financing of higher education in Kyrgyzstan. Russian Education and Society, 50 (1), 75-88. http://doi.org/10.2753/RES1060-9393500105

University of Central Asia. (n.d.). About the University of Central Asia. https://ucentralasia.org/About/Index/EN

USAID in the Kyrgyz Republic. (2017). Supporting equity through national admission testing. https://www.usaid.gov/kyrgyz-republic/fact-sheets/national-admissiontest-nat-project

\section{About the Authors}

Martha C. Merrill worked on higher education reform in the Kyrgyz Republic from 1996 to 2001, and returns regularly for research and consulting. Her work on Central Asia has been published in the journals Asian Education and Development Studies, Higher Education in Russia and Beyond, European Education, International Higher Education, and Central Eurasian Studies Review, as well as in local journals in Kyrgyzstan, and in the books Globalization on the Margins: Education and Post-socialist Transformations in Central Asia; Reimagining Utopias: Theory and Method for Educational Research in Post-Socialist Contexts; PostSoviet Kyrgyzstan: Political and Social Challenges; and The European Union in Central Asia. Dr. Merrill is Associate Professor of Higher Education at Kent State University in Ohio (USA) and Coordinator of the program's International Education Certificate. Her Ph.D. is from the University of Michigan.

Janara Baitugolova is Acting Associate Professor at the Institution of Retraining Teachers at I. Arabaev Kyrgyz State University, in Bishkek, the Kyrgyz Republic. She holds a Candidate of Pedagogical Sciences degree in Theory and Methods of Higher Education. She has written approximately 30 publications on learning outcomes, competency based education, using portfolios in teaching languages and assessment in education.

Chynarkul S. Ryskulova, Ph.D.(USA) and Candidate of Philological Sciences (Ph.D., Kyrgyzstan) is an Associate Professor and Co-chair of the General Education Program at the American University in Central Asia (AUCA), Kyrgyzstan. From 1984 to 1998, she taught English language to Kyrgyz and Russian speaking students at the Kyrgyz National University. She worked at AUCA in various teaching and administrative positions including Dean of Academic Affairs and Coordinator of Writing and Academic Resources Center from 1998 to 2014. She did her Ph.D. in Higher Education Administration at Kent State University (USA) from 2014-2019, and returned to AUCA in 2019. She is one of the four editors of an English-Kyrgyz Dictionary and published several articles on comparative linguistics and issues of higher education in Kyrgyzstan. 